\title{
システムトラス球継手の疲労強度改善に関する研究 IMPROVED FATIGUE PROPERTIES OF JOINT SYSTEM WITH THREADED SPHERICAL NODES
}

\author{
过岡 静雄*1, 木下陵二*2, 古川忠稔*3, 今井克彦*4 \\ Shizuo TSUIIOKA, Ryouji KINOSHITA, Tadatoshi FURUKAWA \\ and Katsuhiko IMAI
}

\begin{abstract}
This system truss has the mechanism to induce the high bolt clamping force. Thus, the initial clamping force reduces the stress range in the bolt under applied cyclic loads and so improves the fatigue life. Moreover, to improve the fatigue properties of space trusses, this paper describes the fatigue tests of the single-bolt joints of system trusses conducted on actual connection models. The test variables are the size (M30, M42), the manufacturing process (rolling and machining) and the stress ratio of the joining bolt. And, for practical applications, the results are presented the S-N diagrams described by the stress range and the fatigue limit diagram. As a result of the tests, the bolt produced by thread rolling after the heat treatment has the better safety against fatigue than that produced by thread rolling before the heat.treatment; thread machining and so on. There is remarkable difference in the fatigue limit by the stress ratio of the joining bolt produced by thread rolling after the heat treatment. And the fatigue design formula can be led from the lower bound by which the $95 \%$ confidence level was shown.
\end{abstract}

Keywords : Space truss, Spherical node, Thread rolling bolt, Screw threaded joint, Fatigue strength 立体トラス, 球節点, 転造ボルト, ねじ接合, 疲労強度

\section{1. はじめに}

建築構造物の大型化 - 複合化に伴い, 高性能材料, 高機能部材や 高品質・高性能接合部が多用されるなど新たな動きが認められる. また, スケール効果により従来無視されてきた疲労破壊や脆性破塄、 などが生じる可能性があり, 地震力や風圧力を受ける構造物の繰返 し応答や疲労などの特性に関する性能把握が要求されている. とこ ろで, 設計の自由度が高くかつ高精度の構造であるシステムトラス ${ }^{1}$ ， 2) は1 本ボルトによる接合機構を有するため, そのボルトの破断は構 造全体の安全性に大きな影響を及ぼす，風圧力や機械振動などの動 的な外力を受ける部分に用いられる場合，ボルトは形状上ねじ部に 切り欠きを持ち疲労に敏感であるため, この特殊ボルトの静的耐力 ばかりでなく疲労強度に配慮することが必要である．特に，接合用 特殊ボルトに大きな軸力が導入できれば，引張接合としての力学特 性を利用した疲労設計が可能である.

既に、システムトラスの接合部の疲労設計のための基礎資料を充 実することを目的として，M20〜M48特殊ボルトを用いた球継手が 片振り引張絽返しを受ける場合の疲労実験を報告し, ボルトの公称 径および応力比によって疲労特性に大きな差異はないが, 高力ボル トより200万回疲労強度は小さいことなどを得て，95\%信頼幅を表す 疲労設計式を導いている3)。これらの特殊ボルトの製造に関して，太
径の特殊ボルトはねじ切削後熱処理で製作されている. 従来より， ねじ切削のボルトでは疲労限度は平均応力に無関係であるが, 熱処 理後ねじ転造のボルトは疲労強度が上昇して疲労限度が大きく向上 することなどムフ が知られているので，太径をねじ転造で製作するこ とにより接合部の疲労強度が改善できると考えられる.

本報では，M30，M42特殊ボルトを用いた球継手の疲労実験により システムトラ.ス接合部の疲労強度の改善に関する設計資料および設 計式を提示する. 実験時期によりシリーズ I〜IIIがあり，シリーズ I では転造ボルトの疲労特性を, シリーズII，IIIではボルトの各製造方 法や転造ボルトの径による疲労特性の変動を検討・考察した.

\section{2. 試験体と実験方法}

システムトラスの接合形式として, 本研究では図 1 に示す形式を 対象とした．この立体トラス接合部2,3) ではボルトに大きなトルクの 導入, すなわち, 高い軸力の導入が可能な機構を有する. 疲労設計 時にはこの特殊ボルトに長期許容引張耐力に相当する張力が導入さ れる. 現システムでは使用ボルトはM5 6 までで, 太径ボルトに対し ては導入トルクおよび有効断面積の点から細目ねじを用い, 熱処理 の点についても配慮している. なお, 現在のシステムトラスにおけ る使用材料の機械的性質の規格值を表 1 に示す.

注）本論文は参考文献8)～9）で発表したものに加籍して取りまとめたものである。

*1 福井工業大学工学部建設工学科 教授. 工博

*2 川鉄シビル(侏) 部長補・工修

*3 大阪大学大学院地球総合工学専攻 学内講師. 工博

Prof., Faculty of Eng., Fukui Institute of Technology, Dr. Eng.

*4 大阪大学大学院地球総合工学専攻 教授. 工博 
試験体はノード，特殊ボルト，スリーブと厚板( スタブコーンに相 当）からなるトラス節点の単純モテルルで, 実験変数は, 特殊ボルトの

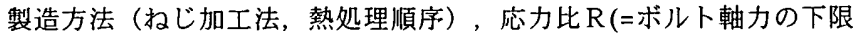
值と上限値との比) , ボルト径で, ボルト初期導入軸力は零とした. ここに，特殊ボルトはM $30 \times 3 ， \mathrm{M} 42 \times 3$ とし，SCM435材をねじ転造後 熱処理(以後 RH と略す), 熱処理後ねじ転造(以後 HR と略す), ねじ切 削後熱処理(以後MH之略す)および熱処理後ねじ切削(以後HM と略す) の各方法で製造するものとし，各シリーズにおいて同径のボルトは 同一ロットの棒鋼より切り出すように計画した．なお，従来の特殊 ボルト(ねじ切削後熱処理ボルト)の実験結果 ${ }^{3}$ もも比較の対象とした. 各シリーズの使用ボルトの形状寸法を図 2 に, 各特殊ボルトの完成 品引張試験結果も表 2 に示す。ここに, 応力度はボルトの有効断面 積を用いて求めた。なお，ボルト記号はボルトの呼び径，製造方法 の順に表されている.

今回の実験では引張繰返し荷重を対象として，50 t 油圧サーボ式 構造物疲労試験装置を用いて周波数 $2 \sim 6 \mathrm{~Hz}$ の正弦波の定常波試験を 行った(図 3). なお, シリーズ II，III では上下のボルト径を同一とし た. 疲労試験では, 応力比 0(0-to-tension)の片振り加力(下限荷重を $0.5 \mathrm{t}$ )を標準とし, 締付け力導入の場合のボルト軸力変動幅を再現す るため, 応力比 $7 / 10,8 / 10$ も設定した

\section{3．実験結果と考察}

破壊回数 $\mathrm{N}$, 応力度と破断位置を表 3 に, 疲労試験結果(両対数 S$\mathrm{N}$ 線図) を図 4，5に示す．また，破壊した実験点に対して最小二乗 法を用いて求めた各回帰直線式を表 4 に揭げる.ここに，応力範囲 はボルトの最大応力度と最小応力度の差 $\mathrm{S}$ (=応力振幅の 2 倍)で, 各応 力度は特殊ボルトの有効断面積を用いて求めた值である.なお， シ リーズ IのM30特殊ボルト(M30MH)については既往の実験結果 ${ }^{3)}$ も合 わせて考察することとした

疲労破壊はノードではなく特殊ボルトねじ部で生じ，シリーズ I で は相対的にアンカーナット部の第 1 ねじ部の破壊が支配的である. シリーズ II ，III ではノード端面位置でのポルトねじ部の破壊が $6 〜 7$ 割となり，ねじ長さの変更の影響が認められる。これは，アンカー ナット第 1 ねじ部がアンカーナット側の不完全ねじ部から離れるか らである．なお，シリーズ I の熱処理後ねじ転造ボルトの一部に軸部 のコーンとの接触部分とアンカーナット側ねじ部との連成による破 壊が認められた。 ( \pm 50 ton, $\pm 150 \mathrm{~mm}$ )

表 2 ボルトの完成品引張試験結果

\begin{tabular}{|c|c|c|}
\hline \multirow{4}{*}{ Series } & Bolt & $\begin{array}{c}\text { Tens ile Strength } \\
\sigma \text { в(MPa) }\end{array}$ \\
\hline \multirow{4}{*}{ I } & M30MH & 1020 \\
\cline { 2 - 3 } & M30RH & 1029 \\
\cline { 2 - 3 } II & M30HR & 1076 \\
\hline \multirow{5}{*}{ III } & M30MH & 1141 \\
\cline { 2 - 3 } & M30HM & 1074 \\
\cline { 2 - 3 } & M30RH & 1014 \\
\cline { 2 - 3 } & M30HR & 1016 \\
\hline \multirow{4}{*}{} & M30RH & 989 \\
\cline { 2 - 3 } & M30HR & 1111 \\
\cline { 2 - 3 } & M42RH & 977 \\
\cline { 2 - 3 } & M42HR & 997 \\
\hline
\end{tabular}
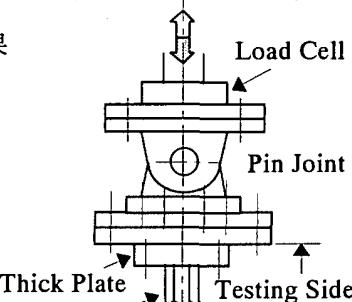
Bolt(M30)

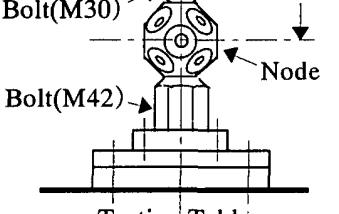

Testing Table

図 3 実験装置概要（シリーズ I )

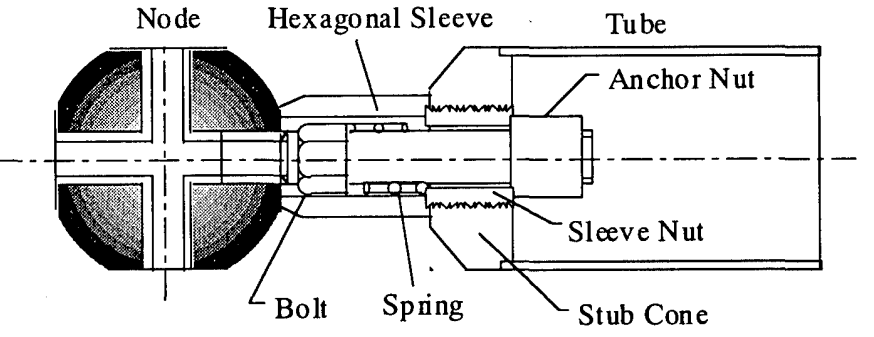

図 1 立体トラス節点

表 1 材料の機械的性質（規格值）

\begin{tabular}{|c|c|c|c|c|c|c|}
\hline \multicolumn{3}{|c|}{ Material, Grade } & $\begin{array}{l}\text { Tensile } \\
\text { St rength } \\
(\mathrm{MPa})\end{array}$ & $\begin{array}{l}\text { Yield } \\
\text { Stress } \\
(\mathrm{MPa})\end{array}$ & $\begin{array}{c}\text { Elong. } \\
\%\end{array}$ & $\begin{array}{c}\text { Hardness } \\
\text { HRC }\end{array}$ \\
\hline \multirow[t]{2}{*}{ Bolt } & M12-M36 & \multirow{2}{*}{ SCM435 } & $\geqq 1000$ & $\geqq 900$ & $\geqq 15$ & $29 \sim 33$ \\
\hline & M42-M56 & & $\geqq 950$ & $\geqq 850$ & $\geqq 15$ & $29 \sim 33$ \\
\hline \multicolumn{2}{|c|}{ Anchor Nut } & SCM435 & $\geqq 900$ & $\geqq 800$ & $\geqq 15$ & $29 \sim 36$ \\
\hline \multicolumn{2}{|c|}{ Node } & SCM435 & $\geqq 900$ & $\geqq 800$ & $\geqq 15$. & $27 \sim 36$ \\
\hline \multicolumn{2}{|c|}{ Sleeve Nut } & SCM435 & $\geqq 700$ & $\geqq 500$ & $\geqq 17$ & $25 \sim 30$ \\
\hline \multicolumn{2}{|c|}{ Hexagonal Sleeve } & S45C & $\geqq 700$ & $\geqq 500$ & $\geqq 17$ & $25 \sim 30$ \\
\hline \multicolumn{2}{|c|}{ Stub Cone } & SS 400 & $\geqq 410$ & $\geqq 240$ & $\geqq 23$ & - \\
\hline
\end{tabular}

注）熱処理条件：・焼き入れ： $870^{\circ} \mathrm{C}$ ，2時間保持，油冷 ・焼き戻し： $620^{\circ} \mathrm{C}, 4$ 時間保持, 徐冷

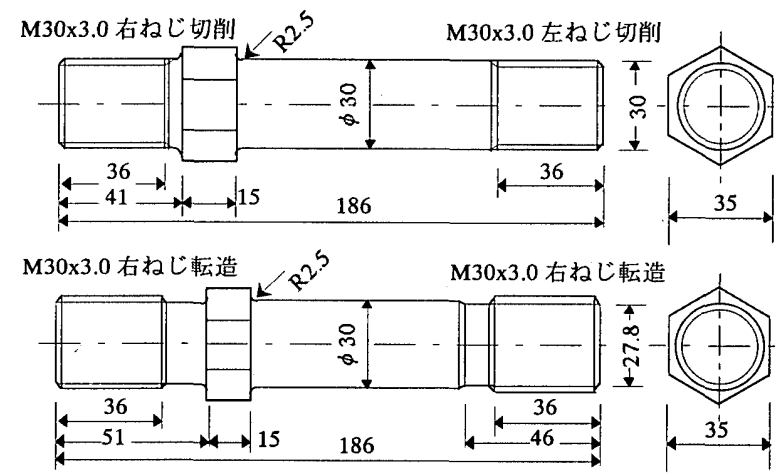

(a) シリーズ I

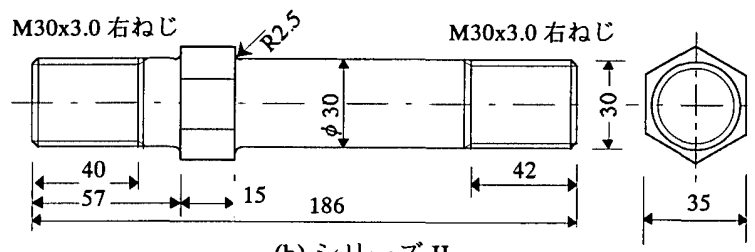

(b) シリーズ II
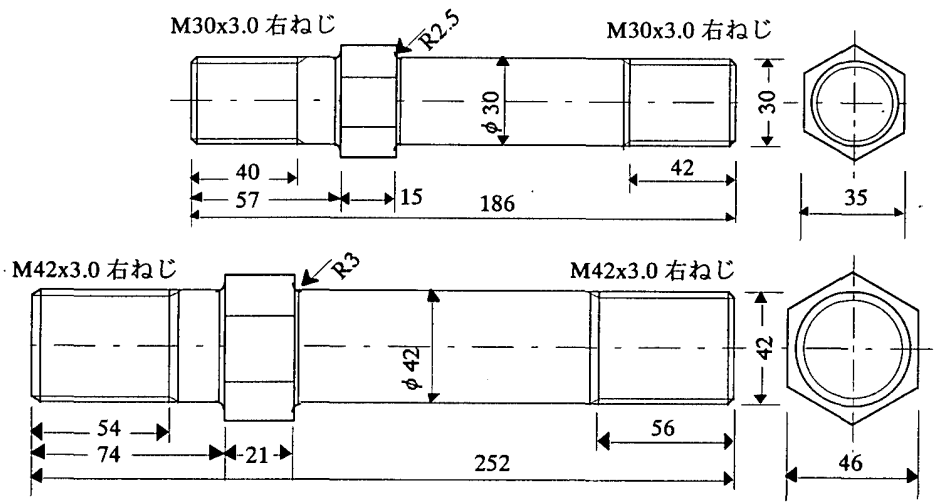

(c) シリーズ III

図 2 特殊ボルト 
ところで, 図 4 の応力範囲で表した疲労強度は, 製造方法や応力 比に大きく影響され，1本のS-N線図で近似することは難しいと考 えられる. 即ち, 応力比 0 に関して, シリーズIでは, ねじ切削後熱 処理の実験点は応力比にかかわらずほぼ 1 本の直線として表される が, ねじ転造後熱処理では切削に比べ疲労強度が若干上昇し, しか も，200万回の繰返しに耐える最大の応力範囲として定義した疲労限 度が大きくなる．また，熱処理後ねじ転造では，その特性はねじ転 造後熱処理と同様な傾向を示すが，疲労強度の大幅な改善が可能 で，ねじ転造後熱処理の 2 倍程度となる。これは，転造ボルトの補 正係数が1.7〜2.0であること4) と合致すると言える. さらに, 応力比 が7/10の疲労強度は下限を示し, 疲労限度も低下する傾向が認められ る.一一方、シリーズ II , III では熱処理後ねじ転造以外は同程度の疲労 強度であり，応力比の影響も小さくなった．次に，ボルト呼び径の 影響については，熱処理後ねじ転造・放じ転造後熱処理共，M30 特 殊ボルトに比ベM4 2 特殊ボルトの疲労強度, 疲労限度は低下する傾 向にある。

本実験では，転造に伴う表面圧縮残留応力・加工硬化・表面の平 滑さによる疲労強度の上昇, 平均応力の存在による疲労限度の変 動，ねじ底での局所的な塑性化による切欠き効果の低減，ねじ切削 による表面きずによる疲労強度の低下の諸効果が疲労強度に影響を 与えていると考えられるが，特に，ねじ転造による残留応力などや 平均応力の疲労限度への影響をM 30 特殊ボルトにおいて検討する.

表 3 -a 実験結果（シリーズI）

\begin{tabular}{|c|c|c|c|c|c|c|c|}
\hline Series & No & Bolt & $\begin{array}{l}\text { Cycles to } \\
\text { Failure N }\end{array}$ & $\begin{array}{l}\text { Maximum } \\
\text { St ress }(\mathrm{MPa})\end{array}$ & $\begin{array}{c}\text { St ress Range } \\
\mathrm{S}(\mathrm{MPa})\end{array}$ & \begin{tabular}{|l} 
Stress \\
Ratio R \\
\end{tabular} & $\begin{array}{c}\text { Failure } \\
\text { Mode }\end{array}$ \\
\hline \multirow{38}{*}{ I } & 1 & \multirow{21}{*}{ M30RH } & 16606 & 388.9 & 380.4 & 0.022 & anchor \\
\hline & 2 & & 26276 & 304.3 & 295.9 & 0.028 & anchor \\
\hline & 3 & & 220704 & 202.9 & 194.4 & 0.042 & node \\
\hline & 4 & & 52821 & 253.6 & 245.2 & 0.033 & anchor \\
\hline & 5 & & 176805 & 186,0 & 177.5 & 0.045 & anchor \\
\hline & 6 & & 1422046 & 152.2 & 143.7 & 0.056 & node \\
\hline & 7 & & 73948 & 219.8 & 211.3 & 0.038 & anchor \\
\hline & 8 & & 157423 & 169.1 & 160.6 & 0.050 & node \\
\hline & 9 & & 419001 & 160.6 & 152.2 & 0.053 & anchor \\
\hline & 10 & & 7883 & 507.2 & 498.8 & 0.017 & anchor \\
\hline & 11 & & 859672 & 143.7 & 135.3 & 0.059 & node \\
\hline & 12 & & 150151 & 202.9 & 194.4 & 0.042 & anchor \\
\hline & 13 & & 1807618 & 135.3 & 126.8 & 0.063 & node \\
\hline & 14 & & 97687 & 558.0 & 169.1 & 0.697 & anchor \\
\hline & 15 & & 279638 & 439.6 & 135.3 & 0.692 & anchor \\
\hline & 16 & & 325267 & 388.9 & 118.4 & 0.696 & node \\
\hline & 17 & & 975560 & 338.2 & 101.4 & 0.700 & anchor \\
\hline & 18 & & 2000000 & 304.3 & 91.3 & 0.700 & - \\
\hline & 19 & & 818665 & 490.3 & 98.1. & 0.800 & anchor \\
\hline & 20 & & 2000000 & 456.5 & 91.3 & 0.800 & - \\
\hline & 21 & & 415753 & 591.8 & 118.4 & 0.800 & anchor \\
\hline & 22 & \multirow[t]{14}{*}{$\mathrm{M} 30 \mathrm{HR}$} & 37362 & 507.2 & 498.8 & 0.017 & anchor \\
\hline & 23. & & 25415 & 583.3 & 574.9 & 0.014 & anchor \\
\hline & 24 & & 83875 & 422.7 & 414.2 & 0.020 & anchor \\
\hline & 25 & & 46920 & 465.0 & 456.5 & 0.018 & anchor \\
\hline & 26 & & 110530 & 388.9 & 380.4 & 0.022 & anchor \\
\hline & 27 & & 371463 & 355.1 & 346.6 & 0.024 & anchor \\
\hline & 28 & & 1248682 & 321.3 & 312.8 & 0.026 & anchor \\
\hline & 29 & & 586769 & 583.3 & 175.0 & 0.700 & anchor \\
\hline & 30 & & 1301679 & 541.1 & 162.3 & 0.700 & anchor \\
\hline & 31 & & 1177372 & 507.2 & 152.2 & 0.700 & anchor \\
\hline & 32 & & 524110 & 642.5 & 192.8 & 0.700 & anchor* \\
\hline & 33 & & 2000000 & 583.3 & 116.7 & 0.800 & - \\
\hline & 34 & & 1129827 & 642.5 & 128.5 & 0.800 & anchor \\
\hline & 35 & & 1699712 & 473.4 & 142.0 & 0.700 & anchor* \\
\hline & 36 & \multirow[t]{3}{*}{$\mathrm{M} 30 \mathrm{MH}$} & 800776 & 405.8 & 81.2 & 0.800 & anchor \\
\hline & 37 & & 840137 & 372.0 & 74.4 & 0.800 & anchor \\
\hline & 38 & & 1342050 & 338.2 & 67.6 & 0.800 & anchor \\
\hline
\end{tabular}

Note：・anchorはアンカーナ部の第一ねじ部破壊，nodeはノード端面位置でのねじ部破壦 *印は軸部とねじ部の連成破断
表 $3 \cdot b$ 実験結果（シリーズII, III）

\begin{tabular}{|c|c|c|c|c|c|c|c|}
\hline Series & No & Bolt & $\begin{array}{l}\text { Cycles to } \\
\text { Failure N }\end{array}$ & $\begin{array}{l}\text { Maximum } \\
\text { St ress(MPa) } \\
\end{array}$ & $\begin{array}{c}\text { Stress Range } \\
\text { S(MPa) }\end{array}$ & $\begin{array}{l}\text { Stress } \\
\text { Ratio R }\end{array}$ & $\begin{array}{l}\text { Failure } \\
\text { Mode }\end{array}$ \\
\hline \multirow{48}{*}{ II } & 1 & \multirow{14}{*}{ M30RH } & 1210544 & 118.4 & 109.9 & 0.071 & node \\
\hline & 2 & & 1161087 & 101.4 & 93.0 & 0.083 & node \\
\hline & 3 & & 242023 & 152.2 & 143.7 & 0.056 & node \\
\hline & 4 & & 77722 & 186.0 & 177.5 & 0.045 & node \\
\hline & 5 & & 74674 & 219.8 & 211.3 & 0.038 & node \\
\hline & 6 & & 44046 & 253.6 & 245.2 & 0.033 & node \\
\hline & 7 & & 27014 & 304.3 & 295.9 & 0.028 & node \\
\hline & 8 & & 15187 & 388.9 & 380.4 & 0.022 & node \\
\hline & 9 & & 1246251 & 93.0 & 84.5 & 0.091 & node \\
\hline & 10 & & 1525918 & 84.5 & 76.1 & 0.100 & node \\
\hline & 11 & & 110925 & 558.0 & 169.1 & 0.697 & anchor \\
\hline & 12 & & 294576 & 388.9 & 118.4 & 0.696 & node \\
\hline & 13 & & 667307 & 338.2 & 101.4 & 0.700 & node \\
\hline & 14 & & 1934716 & 287.4 & 84.5 & 0.706 & node \\
\hline & 15 & \multirow{13}{*}{ M30HR } & 22466 & 439.6 & 431.2 & 0.019 & node \\
\hline & 16 & & 48020 & 388.9 & 380.4 & 0.022 & node \\
\hline & 17 & & 91124 & 346.6 & 338.2 & 0.024 & node \\
\hline & 18 & & 255700 & 304.3 & 295.9 & 0.028 & anchor \\
\hline & 19 & & 401937 & 245.2 & 236.7 & 0.034 & anchor \\
\hline & 20 & & 977864 & 211.3 & 202.9 & 0.040 & node \\
\hline & 21 & & 2000000 & 186.0 & 177.5 & 0.045 & - \\
\hline & 22 & & 138212 & 642.5 & 192.8 & 0.700 & anchor \\
\hline & 23 & & 200077 & 642.5 & 192.8 & 0.700 & anchor \\
\hline & 24 & & 1034064 & 541.1 & 162.3 & 0.700 & anchor \\
\hline & 25 & & 1440755 & 473.4 & 142.0 & 0.700 & anchor \\
\hline & 26 & & 1854748 & 642.5 & 128.5 & 0.800 & anchor \\
\hline & 27 & & 782512 & 583.3 & 116.7 & 0.800 & anchor \\
\hline & 28 & \multirow{11}{*}{$\mathrm{M} 30 \mathrm{MH}$} & 237945 & 152.2 & 143.7 & 0.056 & node \\
\hline & 29 & & 399343 & 118.4 & 109.9 & 0.071 & node \\
\hline & 30 & & 70693 & 219.8 & 211.3 & 0.038 & node \\
\hline & 31 & & 29231 & 304.3 & 295.9 & 0.028 & node \\
\hline & 32 & & 13270 & 388.9 & 380.4 & 0.022 & node \\
\hline & 33 & & 2000000 & 93.0 & 84,5 & 0.091 & - \\
\hline & 34 & & 344156 & 388.9 & 118.4 & 0.696 & anchor \\
\hline & 35 & & 859500 & 338.2 & 101.4 & 0.700 & node \\
\hline & 36 & & 1545836 & 287.4 & 84.5 & 0.706 & node \\
\hline & 37 & & 119403 & 558.0 & 169.1 & 0.697 & node \\
\hline & 38 & & 1610190 & 253.6 & 76.1 & 0.700 & node \\
\hline & 39 & \multirow[t]{10}{*}{ M30HM } & 161828 & 152.2 & 143.7 & 0.056 & node \\
\hline & 40 & & 60177 & 219.8 & 211.3 & 0.038 & node \\
\hline & 41 & & 1402495 & 93.0 & 84.5 & 0.091 & node \\
\hline & 42 & & 329512 & 118.4 & 109.9 & 0.071 & node \\
\hline & 43 & & 25729 & 304.3 & 295.9 & 0.028 & node \\
\hline & 44 & & 18463 & 388.9 & 380.4 & 0.022 & node \\
\hline & 45 & & 385574 & 388.9 & 118.4 & 0.696 & anchor \\
\hline & 46 & & 1466731 & 338.2 & 101.4 & 0.700 & anchor \\
\hline & 47 & & 2000000 & 287.4 & 84.5 & 0.706 & - \\
\hline & 48 & & 117091 & 558.0 & 169.1 & 0.697 & anchor \\
\hline \multirow{27}{*}{ III } & 1 & \multirow{14}{*}{ M30RH } & 1323586 & 109.9 & 101.4 & 0.077 & node \\
\hline & 2 & & 292399 & 131.0 & 122.6 & 0.065 & node \\
\hline & 3 & & 131972 & 152.2 & 143.7 & 0.056 & anchor \\
\hline & 4 & & 74854 & 202.9 & 194.4 & 0.042 & node \\
\hline & 5 & & 22410 & 304.3 & 295.9 & 0.028 & node. \\
\hline & 6 & & 2000000 & 84.5 & 76.1 & 0.100 & - \\
\hline & 7 & & 129718 & 558.0 & 169.1 & 0.697 & node \\
\hline & 8 & & 366882 & 422.7 & 126.8 & 0.700 & anchor \\
\hline & 9 & & 687833 & 338.2 & 101.4 & 0.700 & node \\
\hline & 10 & & 1387994 & 287.4 & 86.2 & 0.700 & node \\
\hline & 11 & & 193741 & 760.9 & 152.2 & 0.800 & anchor \\
\hline & 12 & & 296403 & 676.3 & 135.3 & 0.800 & ancho \\
\hline & 13 & & 828551 & 507.2 & 101.4 & 0.800 & ancho \\
\hline & 14 & & 2000000 & 422.7 & 84.5 & 0.800 & - \\
\hline & 15 & $\mathrm{M} 30 \mathrm{HR}$ & 26378 & 448.1 & 439.6 & 0.019 & anchor \\
\hline & 16 & & 44360 & 397.3 & 388.9 & 0.021 & anchor \\
\hline & 17 & & 73045 & 346.6 & 338.2 & 0.024 & node \\
\hline & 18 & & 408499 & 304.3 & 295.9 & 0.028 & anchor \\
\hline & 19 & 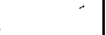 & 711317 & 253.6 & 245.2 & 0.033 & ancho \\
\hline & 20 & & 2000000 & 202.9 & 194.4 & 0.042 & - \\
\hline & 21 & & 247597 & 642.5 & 192.8 & 0.700 & anchor \\
\hline & 22 & & 392344 & 574.9 & 172.5 & 0.700 & anchor \\
\hline & 23 & & 844278 & 439.6 & 131.9 & 0.700 & node \\
\hline & 24 & & 2000000 & 417.6 & 125.1 & 0.700 & - \\
\hline & 25 & & 718960 & 490.3 & 147.1 & 0.700 & node \\
\hline & 26 & & 753421 & 676.3 & 135.3 & 0.800 & anchor \\
\hline & 27 & & 2000000 & 642.5 & 128.5 & 0.800 & 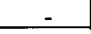 \\
\hline
\end{tabular}


表 3 -c 実験結果（シリーズIII）

\begin{tabular}{|c|c|c|c|c|c|c|c|}
\hline Series & $\mathrm{No}$ & Bolt & $\begin{array}{l}\text { Cycles to } \\
\text { Failure N }\end{array}$ & \begin{tabular}{|l|} 
Maximum \\
Stress(MPa) \\
\end{tabular} & $\begin{array}{c}\text { St ress Rang } \\
\text { S (MPa) }\end{array}$ & $\begin{array}{l}\text { Stress } \\
\text { Ratio R } \\
\end{array}$ & $\begin{array}{l}\text { Failure } \\
\text { Made }\end{array}$ \\
\hline \multirow{28}{*}{ III } & 28 & \multirow{15}{*}{ M42RH } & 157280 & 121.6 & 117.5 & 0.033 & node \\
\hline & 29 & & 53064 & 182.4 & 178.3 & 0.022 & node \\
\hline & 30 & & 251253 & 101.3 & 97.3 & 0.040 & node \\
\hline & 31 & & 811245 & 64.8 & 60.8 & 0.063 & anchor \\
\hline & 32 & & 2000000 & 52.7 & 48.6 & 0.077 & \\
\hline & 33 & & 44046 & 253.6 & 245.2 & 0.033 & node \\
\hline & 34 & & 27014 & 304.3 & 295,9 & 0.028 & node \\
\hline & 35 & & 15187 & 388.9 & 380.4 & 0.022 & node \\
\hline & 36 & & 1246251 & 93.0 & 84.5 & 0.091 & node \\
\hline & 37 & & 1525918 & 84.5 & 76.1 & 0.100 & node \\
\hline & 38 & & 795530 & 243.1 & 72.9 & 0.700 & node \\
\hline & 39 & & 360593 & 269.9 & 81.0 & 0.700 & anchor \\
\hline & 40 & & 377099 & 297.4 & 89.2 & 0.700 & node \\
\hline & 41. & & 1031720 & 188.8 & 56.7 & 0.700 & anchor \\
\hline & 42 & & 2000000 & 162.1 & 48.6 & 0,700 & \\
\hline & 43 & \multirow{13}{*}{ M42HR } & 82528 & 299.9 & 295.8 & 0.014 & anchor \\
\hline & 44 & & 197627 & 263.4 & 259.3 & 0.015 & node \\
\hline & 45 & & 392695 & 222.9 & 218.8 & 0.018 & anchor \\
\hline & 46 & & 814502 & 210.7 & 206.7 & 0.019 & node \\
\hline & 47 & & 2000000 & 198.6 & 194.5 & 0.020 & \\
\hline & 48 & & 44046 & 253.6 & 245.2 & 0.033 & node \\
\hline & 49 & & 27014 & 304.3 & 295.9 & 0,028 & node \\
\hline & 50 & & 15187 & 388.9 & 380.4 & 0.022 & node \\
\hline & 51 & & 1246251 & 93.0 & 84.5 & 0.091 & node \\
\hline & 52 & & 1525918 & 84.5 & 76.1 & 0.100 & node \\
\hline & 53 & & 816481 & 364.7 & 109.4 & 0,700 & anch \\
\hline & 54 & & 1350609 & 324.2 & 97.3 & 0.700 & node \\
\hline & 55 & & 2000000 & 291.8 & 87.5 & 0.700 & \\
\hline
\end{tabular}

表 4 回帰直線式

\begin{tabular}{|c|c|c|c|}
\hline Series & Bolt & Loading type & $\sigma \max -\sigma \min$ \\
\hline \multirow{6}{*}{ I } & \multirow{2}{*}{ M30MH } & 0 -to-tension & $\log S=-0.3208 \log N+3.803$ \\
\hline & & 7/10-to-tension & $\log S=-0.2549 \log N+3.426$ \\
\hline & \multirow{2}{*}{ M30RH } & 0 -to-tension & $\log S=-0.2349 \log N+3.526$ \\
\hline & & 7/10-to-tension & $\log S=-0.2245 \log N+3.340$ \\
\hline & \multirow{2}{*}{ M30HR } & 0 -to-tension & $\log S=-0.1447 \log N+3.350$ \\
\hline & & 7/10-to-tension & $\log S=-0.2154 \log N+3.503$ \\
\hline \multirow{8}{*}{ II } & \multirow{2}{*}{ M30MH } & 0 -to-tension & $\log S=-0.3581 \log N+4.064$ \\
\hline & & $7 / 10$-to-tension & $\log S=-0.2793 \log N+3.640$ \\
\hline & \multirow{2}{*}{ M30HM } & 0 -to-tension & $\log S=-0.3488 \log N+5.014$ \\
\hline & & 7/10-to-tension & $\log S=-0.2200 \log N+3.330$ \\
\hline & \multirow{2}{*}{ M30RH } & 0 -to-tension & $\log S=-0.3078 \log N+3.825$ \\
\hline & & 7/10-to-tension & $\log S=-0.2374 \log N+3.402$ \\
\hline & \multirow{2}{*}{ M30HR } & 0 -to-tension & $\log S=-0.2008 \log N+3.520$ \\
\hline & & 7/10-to-tension & $\log S=-0.1215 \log N+2.920$ \\
\hline \multirow{9}{*}{ III } & \multirow{3}{*}{ M30RH } & 0 -to-tension & $\log S=-0.2646 \log N+3.575$ \\
\hline & & 7/10-to-tension & $\log S=-0.2895 \log N+3.708$ \\
\hline & & 8/10-to-tension & $\log S=-0.2792 \log N+3.659$ \\
\hline & \multirow{2}{*}{ M30HR } & 0 -to-tension & $\log S=-0.1552 \log N+3.313$ \\
\hline & & 7/10-to-tension & $\log S=-0.2184 \log N+3.451$ \\
\hline & \multirow{2}{*}{ M42RH } & 0 -to-tension & $\log S=-0.3950 \log N+4.120$ \\
\hline & & 7/10-to-tension & $\log S=-0.3335 \log N+3.790$ \\
\hline & \multirow{2}{*}{ M42HR } & 0 -to-tension & $\log S=-0.1648 \log N+3.280$ \\
\hline & & 7/10-to-tension & $\log S=-0.2340 \log N+3.423$ \\
\hline
\end{tabular}

Note : $\mathbf{S}(=\sigma \max -\sigma \mathrm{min})=$ Stress range, $\mathbf{N}=$ Cycles to failure
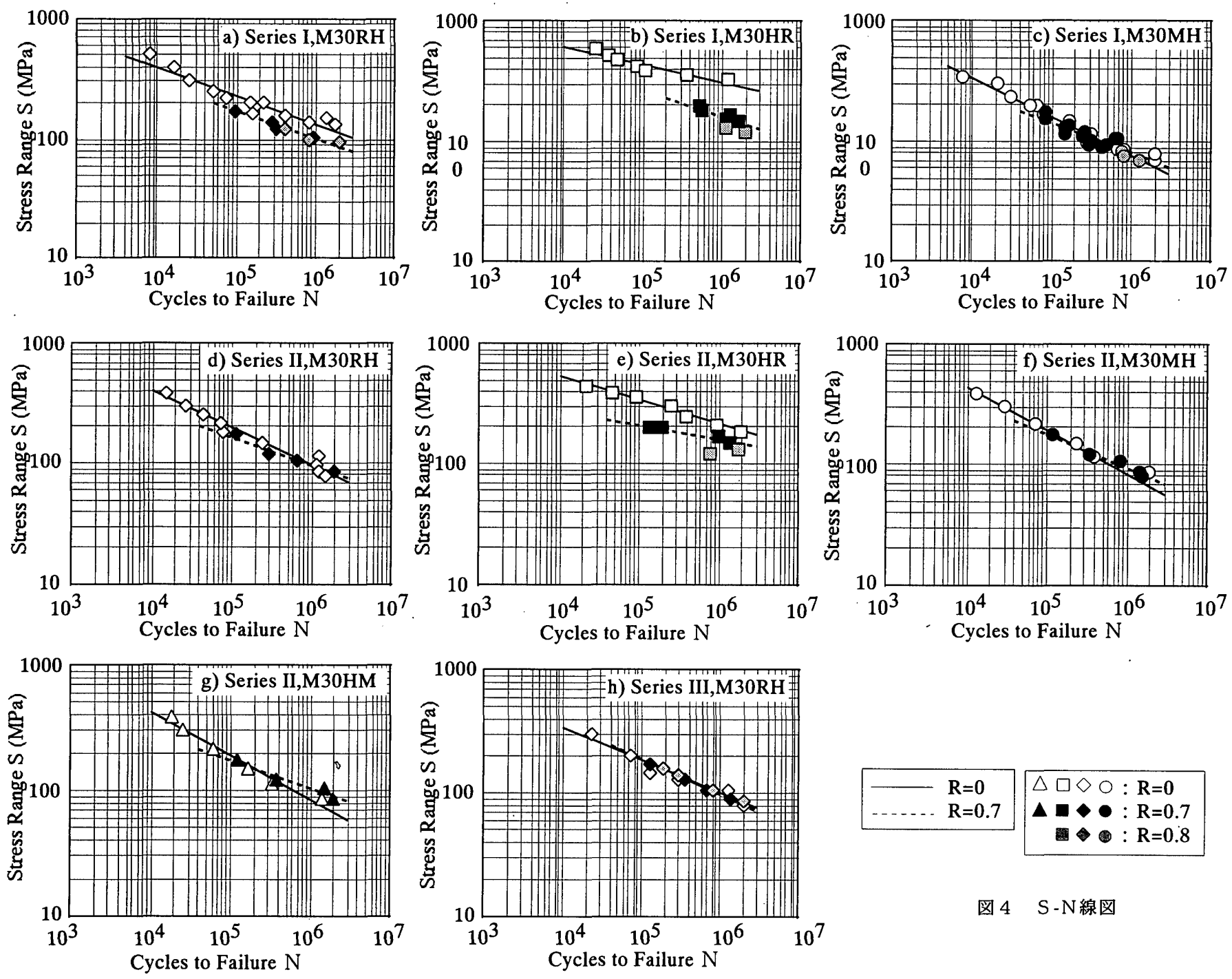

図 4 S-N線図 

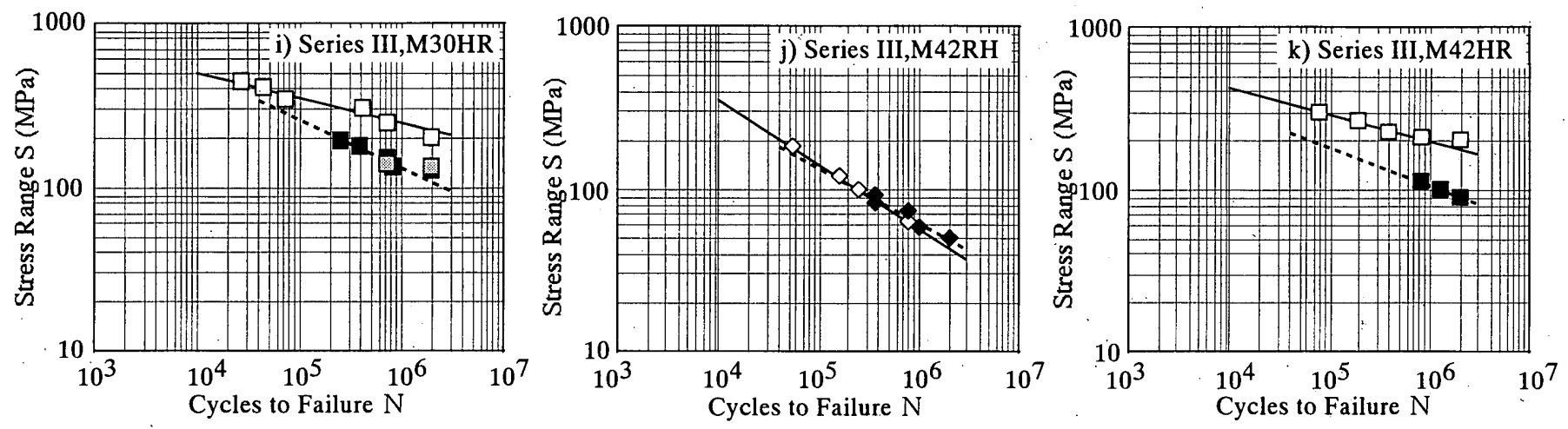

図 4S-N線図（続き）

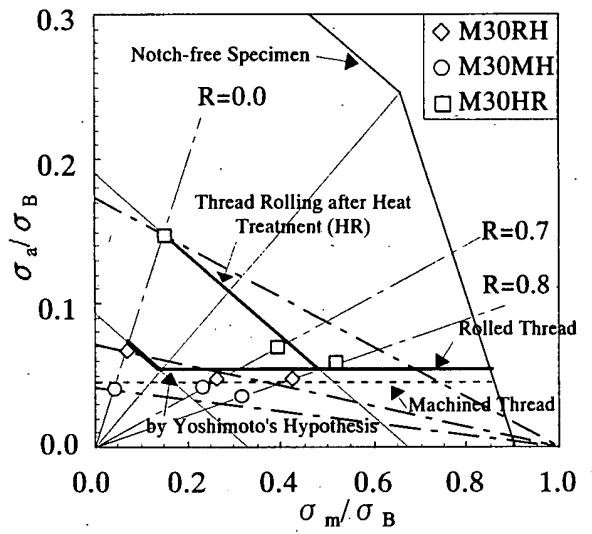

(a) シリーズI

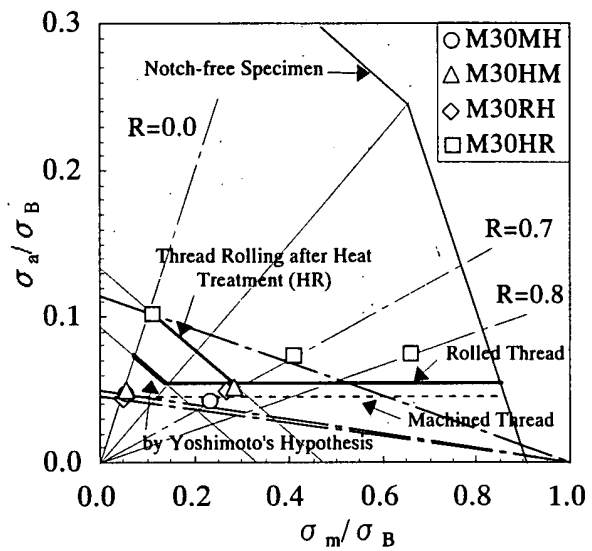

(b) シリーズ II

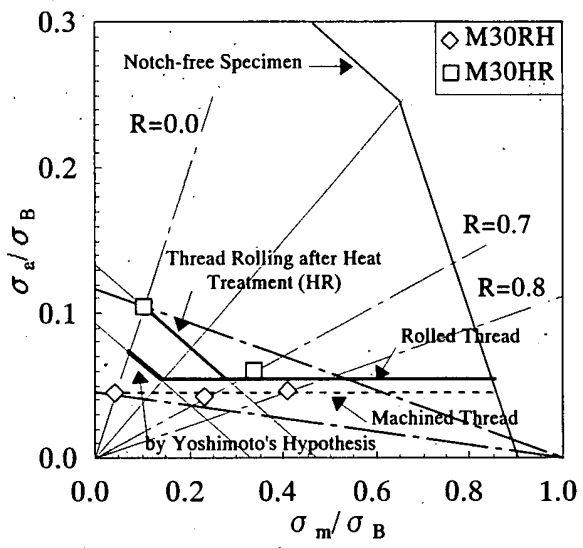

(c) シリーズ III

図 5 疲労限度線図(平均応力 $\sigma_{\cdot \mathrm{m}}$ - 応力振幅 $\sigma_{\mathrm{a}}$ 線図)

図 5 に表 2 の引張強さ $\sigma_{\text {в }}$. で規淮化した疲労限度線図を示す. 図中に

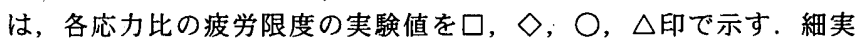
線は平滑材に対する疲労と降伏の安全領域として規定した疲労限度 である. 中太実線は吉本によって提案されたねじ（ボルト・ナット 結合体）の疲労限度に関する仮説 ${ }^{6}$ に従う推定式で, 切欠き係数 $\beta_{\mathrm{k}}$ を M30細目ねじの值 ${ }^{6)} 4.63$ として算出した. 熱処理後ねじ転造ボルトに 対しては, 吉本の仮説に従う推定式を正方向に平行移動させて応力 比 0 の実験值を通る様にすることで疲労限度の線図を得ている. 点線 は山本によって提案された計算式)によって切欠き係数 $\beta_{\mathrm{k}}$ を算定し， 疲労限度が平均応力に依存しないとしたものである. また, 一点鎖 楾は修正Goodman線図で, 応力比 0の実験值を通る様にした線図であ る. 計算に当たっては, SCM435材の材料特性や疲労限度の実験デー 夕 $^{10)}$ の平均値より, 真破断力 $\sigma_{\mathrm{T}}$ は $1590 \mathrm{~N} / \mathrm{mm}^{2}$, 鋼材の降伏点 $\sigma_{y}$, 引 張強さ $\sigma_{\mathrm{B}}$ を各々 $941,1040 \mathrm{~N} / \mathrm{mm}^{2}$, 両振りの疲労限度 $\sigma_{\mathrm{wo}}$ を $451 \mathrm{~N} / \mathrm{mm}^{2}$ とした. 図より, 修正Goodman線図は切削ボルトやねじ転造後熱処理 ボルトでは疲労限度の実験值を評価可能であるが, 熱処理後ねじ転 造ボルトでは過大評価する場合があること, 切削ボルトに対する実 験値はほぼ一定で山本の方法により実駼值を評価可能なことが得ら れた. また, 転造ボルトでは, 吉本の仮説に従う推定式や応力比 0 の 実験値を通る疲労限度の線図が転造ボルトの各応力比の実験值の傾 向を良く表している.すなわち，ねじ転造の影響で疲労限度は平均 応力に依存するが, その程度は加工順序によること, 熱処理後ねじ 転造したものでの線図の平行移動量は約136〜 333 $/ \mathrm{mm}^{2}$ で，これに相 当する圧縮残留応力などがねじ谷底近傍にが存在すると推定される
ことなどが得られる．これらより，切削ボルトやねじ転造後熱処理 ボルトでは平均応力に依存しない山本の方法で, 熱処理後ねじ転造 ボルトでは応力を応力比零の結果に基づく残留応力を考慮した吉本 の仮説で疲労限度を評価できると言える.

\section{4. 疲労設計曲線}

疲労設計を行うには，各応力比の回帰直線(S-N 線図)の傾きと疲労 限度が必要である. 繰返し荷重下で応力比が実際には一定とは限ら ないので疲労限度を応力比で規定することは危険側の場合があるこ と，構造物によっては耐用期間中の作用外力の繰返し回数が数万〜 数十万回と疲労限度 200 万回に比べかなり少ないこと, 高い平均応力 では疲労限度がほぼ一定であることを考慮すれば, 回帰直楾を応力 比とボルト径に無関保として熱処理後ねじ転造とそれ以外の製造法 のボルトに区分して, 疲労限度を一定值(下限値)に置き, 応力比ある いは平均応力に無関係と単純化することが考えられる（図6）.

よって，熱処理後ねじ転造ボルトとそれ以外のボルトの破壊した 実験点全てに対しての各回帰直楾および9 $5 \%$ 信頼幅を図 6 に各々太 線, 細線で, その上下限式を(1) 式に示す. 熱処理後ねじ転造ボルト はそれ以外のボルトに比べ全般にわたって疲労強度は高いが，回㷌 直線式の傾きはいずれもほほ等しいといえる.

一方, 同図には文献 3 で提案した当形式のシステムトラス接合部 （M20〜M48特殊ボルト）の疲労設計式を点線で示すが，その疲労設 計式は切削ボルトや転造後熱処理ボルトの下限式にほぼ対応する。 微小項を無視すれば,この下限式より実用的な疲労設計式として 
<回帰直線 $>$

・熱処理後ねじ転造ボルト：

$\log S=3.999-0.2979 \times \log N \pm 0.2279 \sqrt{1+(\log N-5.499)^{2} / 14.17}$

・それ以外のボルト :

$\log S=3.787-0.3080 \times \log N \pm 0.1575 \sqrt{1+(\log N-5.347)^{2} / 35.56}$

<疲労設計式>

・熱処理後ねじ転造ボルト：

$S \times N^{0.2927}=5901 \quad(S>89.4)$

・それ以外のボルト : $S \times N^{0.3080}=4261 \quad(S>48.8)$

記号, $\mathrm{S}$ : 応力範囲 $\left(\mathrm{N} / \mathrm{mm}^{2}\right), \mathrm{N}$ : 応力の絽返し数

（2）式が導かれ，熱処理後ねじ転造とすることにより $38.5 \%$ の疲労 強度の改善が可能であると言える.

\section{5. 緾め}

本報では，特殊ボルトを用いた立体トラス（システムトラス）の 接合部の疲労強度改善のために特殊ボルトの製造方法, 応力比, ボ ルト径を実験変数として片振り絽返し実験を行い, その疲労特性を 検討・考察した．それらを䌖めれば以下の通りとなる.

1）特殊ボルトの製造方法, 応力比により疲労特性に大きな差異が生 じ，とくに，切削およびねじ転造後熱処理ボルトは応力比にかか わらず同程度であるが，熱処理後ねじ転造ボルトではそれ以外の

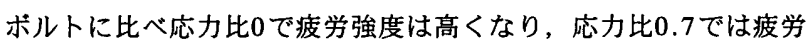
強度が低下する．また，ボル卜呼び径が大きくなれば疲労強度， 疲労限度は低下する傾向にある。

2）疲労限度は切削ボルトでは平均応力に無関係で, 熱処理後ねじ転 造ボルトでは平均応力に依存する. また, 熱処理後転造したもの ではるじ谷底近傍に最大 $333 \mathrm{~N} / \mathrm{m} \mathrm{m}^{2}$ 程度の圧縮残留応力などが存 在すると推定される.

3）接合部の疲労破壊はノード端面位置でのボルトねじ部あるいはア ンカーナット部のボルト第 1 ねじ部で観察された.

4）熱処理後ねじ転造ボルトを使用することにより $38.5 \%$ の疲労強度 の改善が可能で，その実用的な疲労設計式は（2-a）式である.

\section{参考文献}

1）田中淳夫 : 評定からみたシステムトラス構造について, ビルデイングレ 夕ー, PP.1-7, 1988.4.

2) Katsuhiko Imai et al. : PROPOSING A NEW JOINT SYSTEM (KT-SYSTEM) OF SPACE FRAME WITH THREADED SPHERICAL NODES AND IT'S FATIGUE CHARACTERISTICS, IASS Madrid, 1989.

3）辻岡静雄, 山田義智, 安井信行, 今井克彦, 脇山広三: 立体トラス接合部の 疲労特性に関する実驗的研究, 日本建築学会構造系論文集, 第490号, pp.223-228, 1996.12.

4）山本 晃: ねじ締結の理論と計算，羡賢堂，pp.102-122, 1992.

5）日本銅構造協会：銅構造物の疲労設計指針・同解説，技報堂，1993.4.

6）吉本 勇編：ねじ締結体設計のポイント，日本規格協会，pp.136-151, 1992.3.

7) 日本材料学会編：金属材料疲学設計便覧，第 3 版, 養㹂堂, pp.91-92, 1987.

8）辻岡静雄，安井信行，今井克彦：立体卜ラス接合部の疲労強度改善に関する 実験的研究, 日本建築学会近疃支部研究報告集, 第35号·構造系, pp.89-92, 1995.7.

9）辻岡静雄，安井信行，今井克彦: システムトラスの球継手の疲労強度改善に 関する研究, 日本建築学会近膱支部研究報告集, 第38号·構造系, pp.389-392, 1998.7.

10）日本材料学会編：金属材料疲九武験便覧，美留堂，pp.42-43，1968.

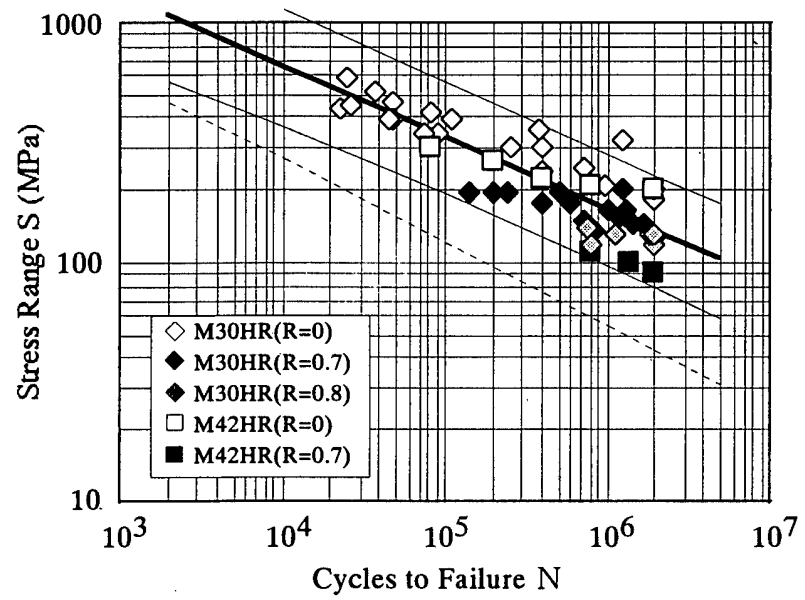

(a) 転造ボルト（HR）

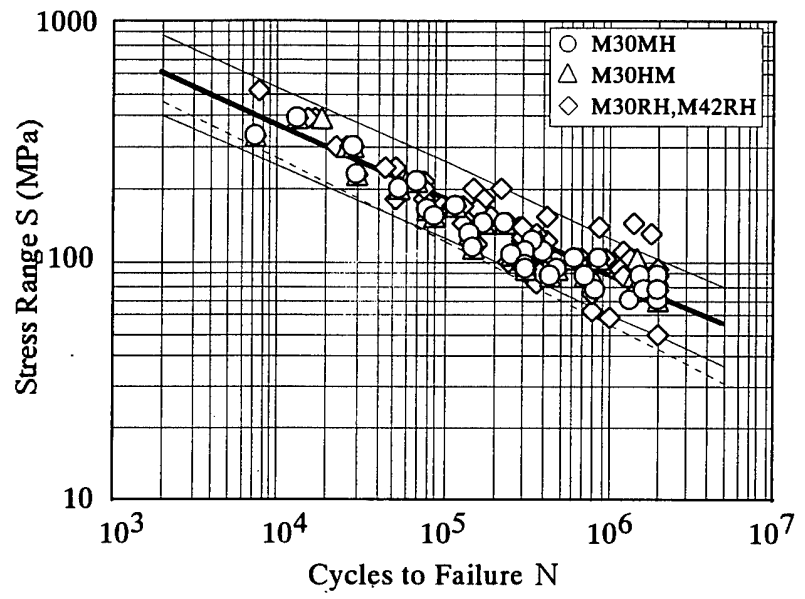

(b) ボルト (MH, HM, RH)

図6 S-N線図（製造方法）

（2002年 3 月 13 日原稿受理， 2002 年 9 月 17 日採用決定） 